\title{
Sequential Detection of Superoxide Anion and Hydrogen Polysulfides under Hypoxic Stress via a Spectral-Response- Separated Fluorescent Probe Functioned with a Nitrobenzene Derivative
}

\author{
Min Gao, ${ }^{\dagger, \ddagger}$ Xia Zhang, ${ }^{\dagger, \ddagger}$ Yue Wang, ${ }^{\dagger \neq}$ Qingluan Liu, ${ }^{\S}$ Fabiao Yu, ${ }^{*}, \| \odot$ Yan Huang, ${ }^{\dagger}$ Caifeng Ding, ${ }^{*, \perp}$ \\ and Lingxin Chen $*, \dagger, \#$ \\ ${ }^{\dagger}$ CAS Key Laboratory of Coastal Environmental Processes and Ecological Remediation, Yantai Institute of Coastal Zone Research, \\ Chinese Academy of Sciences, Yantai 264003, China \\ "Institute of Functional Materials and Molecular Imaging, College of Emergency and Trauma, Hainan Medical University, Haikou, \\ 571199, China

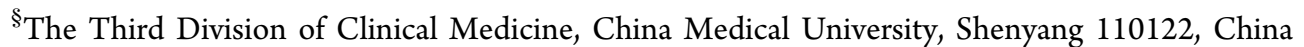 \\ ${ }^{\perp}$ Key Laboratory of Optic-electric Sensing and Analytical Chemistry for Life Science, MOE; College of Chemistry and Molecular \\ Engineering, Qingdao University of Science and Technology, Qingdao 266042, China \\ ${ }^{\ddagger}$ University of Chinese Academy of Sciences, Beijing 100049, China \\ ${ }^{\#}$ Center for Ocean Mega-Science, Chinese Academy of Sciences, Qingdao 266071, China
}

Supporting Information
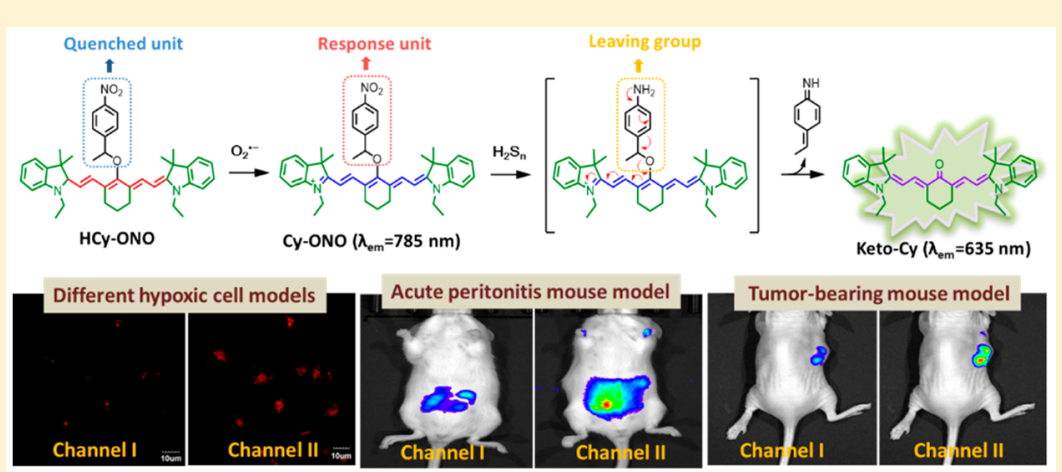

ABSTRACT: Chronic hypoxic stress disrupts the intracellular redox homeostasis, leads to a series of physiological dysfunction, and finally results in many diseases including cancer and inflammatory and cardiovascular diseases. The intracellular redox status is related to the homeostasis between reactive oxygen species (ROS) and cellular antioxidant species. Superoxide anion $\left(\mathrm{O}_{2}{ }^{--}\right)$ is considered to be a precursor of ROS. As a member of reactive sulfur species, hydrogen polysulfides $\left(\mathrm{H}_{2} \mathrm{~S}_{n}\right)$ are a class of antioxidants in cells, which act as an important regulator for the intracellular redox state. Therefore, trapping the cross-talk of $\mathrm{O}_{2}{ }^{-}$and $\mathrm{H}_{2} \mathrm{~S}_{n}$ is a benefit for further understanding the physiological and pathological effects. Herein, we conceive a fluorescent probe $\mathrm{HCy}-\mathrm{ONO}$ for sequential detection of $\mathrm{O}_{2}{ }^{--}$and $\mathrm{H}_{2} \mathrm{~S}_{\mathrm{n}}$ in cells and in mouse models. Based on a tandem reaction, the probe $\mathrm{HCy}-\mathrm{ONO}$ can be used to detect $\mathrm{O}_{2}{ }^{--}$and $\mathrm{H}_{2} \mathrm{~S}_{n}$ in different fluorescence collection windows without spectral overlap interference with limits of detection 90 and $100 \mathrm{nM}$, respectively. The strategy affords high sensitivity and selectivity for our detection in living cell models under continuous hypoxic and intermittent hypoxic conditions, revealing the reason for ischemia-reperfusion injury. Moreover, the probe can distinguish the inflamed tissue from normal tissue in acute peritonitis mouse model. Finally, our probe is successfully applied for imaging of $\mathrm{O}_{2}{ }^{\bullet-}$ and $\mathrm{H}_{2} \mathrm{~S}_{n}$ in the SH-SY5Y tumor-bearing mouse model, which is helpful to elucidate the physiological and pathological processes. These data demonstrated that different hypoxic status lead to different concentrations between $\mathrm{H}_{2} \mathrm{~S}_{n}$ and $\mathrm{O}_{2}{ }^{\bullet-}$.

$\mathrm{T}^{\mathrm{h}}$ he cellular normal physiological activities require accurate oxygen supply. Therefore, hypoxic stress will cause disorders of physiological functions, involving the severe inhibition of the activities of antioxidant enzymes and the abnormal accumulation of reactive oxygen species (ROS). ${ }^{1-5}$

Received: March 7, 2019

Accepted: May 15, 2019

Published: May 15, 2019 
Scheme 1. Structure and Proposed Reaction Mechanism of $\mathrm{HCy}-\mathrm{ONO}$ for $\mathrm{O}_{2}{ }^{\bullet-}$ and $\mathrm{H}_{2} \mathrm{~S}_{n}$ Detection
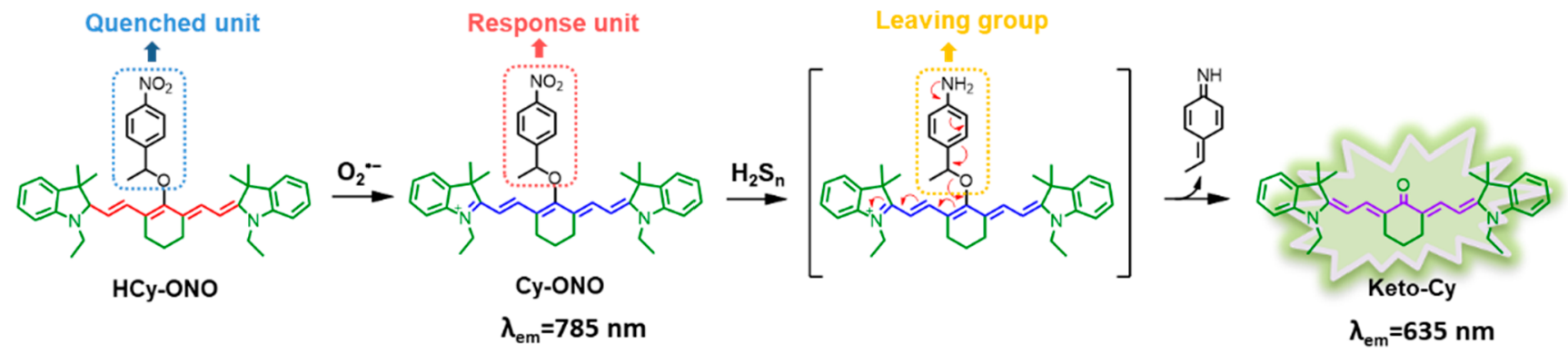

Subsequently, these excessive oxygen-free radicals will interact with large numbers of biomacromolecules, irreversibly destroy the functions of cells, and thus initiate the irregular cell signaling pathways. That is, the imbalance between ROS production and cellular antioxidant capacity is a crucial pathogenic factor. Reactive sulfur species (RSS) behave as important regulators of the intracellular redox state in antioxidant regulatory systems. ${ }^{6-8}$ Among RSS, hydrogen polysulfides $\left(\mathrm{H}_{2} \mathrm{~S}_{n}, n>1\right)$ exhibit highly reducing and nucleophilic abilities, and they are capable of directly scavenging oxidants and intracellular electrophiles. ${ }^{9-12}$ However, $\mathrm{H}_{2} \mathrm{~S}_{n}$ can be generated by the oxidation reaction between endogenous $\mathrm{H}_{2} \mathrm{~S}$ and ROS. ${ }^{13,14}$ Therefore, the appropriate checks and balances between $\mathrm{H}_{2} \mathrm{~S}_{n}$ and ROS drive the intracellular redox homeostasis. Since hypoxic stress can disturb the redox equilibrium of intracellular milieu, the in real-time synchronous monitoring of level changes of $\mathrm{H}_{2} \mathrm{~S}_{n}$ and ROS can be beneficial for further elaborating on the physiological and pathological effects under hypoxic stress. The results may provide us a therapeutic way to ease the damage caused by hypoxia.

Superoxide anion $\left(\mathrm{O}_{2}{ }^{\bullet-}\right)$ acts as a crucial mediator in many physiological and pathological processes. It is controllably produced at a rate that is matched with the catabolize capacity of tissue. ${ }^{15} \mathrm{O}_{2}{ }^{\bullet-}$ is mainly generated in mitochondria, which is immediately transferred into hydrogen peroxide $\left(\mathrm{H}_{2} \mathrm{O}_{2}\right)$, and then induced the production of other ROS. Thus, $\mathrm{O}_{2}{ }^{\bullet-}$ represents the overall levels of ROS in cells. When its generation exceeds the body's intrinsic ability to scavenge, it will lead to a variety of pathological conditions, including cancer, stroke, and neurodegeneration. ${ }^{16,17}$ As known, mitochondria contain $60 \% \mathrm{H}_{2} \mathrm{~S}_{n}$ and their derivatives, which execute indispensable antioxidant and cytoprotective capacities. ${ }^{18,19}$ We suppose that the balance between $\mathrm{H}_{2} \mathrm{~S}_{n}$ and $\mathrm{O}_{2}{ }^{\bullet-}$ may contribute to the normal cellular redox state, although the related investigation is far from full understanding. ${ }^{20,21}$

Due to the high reactivity, low concentration, and short lifetime of $\mathrm{H}_{2} \mathrm{~S}_{n}$ and $\mathrm{O}_{2}{ }^{\bullet-}$ in biological systems, it is of great significance to develop suitable analytical methods to trap them and assess the real-time existence of these reactive species. Fluorescence imaging can meet the above requirements, for it can offer in real-time, in situ and noninvasive imaging analysis. ${ }^{22-26}$ Despite the fact that the fluorescent probes for imaging of $\mathrm{O}_{2}{ }^{\bullet-}$ and $\mathrm{H}_{2} \mathrm{~S}_{n}$ in cells have been elegantly developed. ${ }^{15,27-39}$ However, the separate detection of $\mathrm{H}_{2} \mathrm{~S}_{n}$ and $\mathrm{O}_{2}{ }^{--}$in the same detection system always leads to unsatisfactory spectral overlap, nonhomogeneous distribution, and furthermore, the test conditions are coordinated differently .$^{40,41}$ To overcome these limitations, a probe can be conceived to offer a synchronous response to multispecies under the same test condition. In the past years, some fluorescent probes for the simultaneous and sequential detection of multiple analytes are reported. ${ }^{42-44}$ We hope the synchronous response of both $\mathrm{H}_{2} \mathrm{~S}_{n}$ and $\mathrm{O}_{2}{ }^{\bullet-}$ with a single probe will better clarify the cross-talk between the two biological species in the regulation of signal transduction and redox homeostasis. ${ }^{45-47}$ Therefore, the development of multiresponse fluorescent probe is of great urgency and expectation.

Herein, we reported a spectral-response-separated fluorescent probe functioned with nitrobenzene derivative $\mathrm{HCy}$ ONO for the investigation of the cross-talk of $\mathrm{H}_{2} \mathrm{~S}_{n}$ and $\mathrm{O}_{2}{ }^{--}$ in living cell and in vivo. The probe $\mathrm{HCy}-\mathrm{ONO}$ provided a dual turn-on fluorescence response toward $\mathrm{H}_{2} \mathrm{~S}_{n}$ and $\mathrm{O}_{2}{ }^{\bullet-}$ in different collected windows, which efficiently avoided the interference from spectral overlap. With the help of this single probe, we examined the level changes of $\mathrm{H}_{2} \mathrm{~S}_{n}$ and $\mathrm{O}_{2}{ }^{--}$in living cells under continuous hypoxic and intermittent hypoxic conditions. In addition, $\mathrm{HCy}-\mathrm{ONO}$ could be used to distinguish the different concentrations of $\mathrm{H}_{2} \mathrm{~S}_{n}$ and $\mathrm{O}_{2}{ }^{--}$in inflamed tissue from normal tissue. And our probe was successfully applied for imaging of $\mathrm{H}_{2} \mathrm{~S}_{n}$ and $\mathrm{O}_{2}{ }^{\bullet-}$ in SH-SY5Y tumor-bearing mouse model.

\section{EXPERIMENTAL SECTION}

In Vivo Imaging. BALB/c mice, 25-30 g, were acquired from Binzhou Medical University. Group-housed mice were maintained in a $12: 12 \mathrm{~h}$ light/dark cycle at $22 \pm 2{ }^{\circ} \mathrm{C}$ with free access to food and water for 3-4 days before operation. Mice were anesthetized by inhalation of isoflurane during in vivo imaging.

Establishment of Acute Peritonitis Mouse Model. $\mathrm{BALB} / \mathrm{c}$ mice weighing 25-30 g were selected as experimental mice. According to the reported method, ${ }^{48}$ E. coli $\left(5 \times 10^{7} /\right.$ $\mathrm{mL}$ ) in normal saline was intraperitoneally injected into the intraperitoneal cavity of mouse.

Establishment of the Murine Sarcoma SH-SY5Y Tumor. SH-SY5Y cells were obtained from the Committee on Type Culture Collection of Chinese Academy of Sciences (Shanghai, China). Nude mice were obtained from Beijing Vital River Laboratory Animal Technology Co., Ltd. The 11week-old mice were given an injection of $0.2 \mathrm{~mL}$ of SH-SY5Y cells $\left(3 \times 10^{6} / \mathrm{mL}\right)$ at the intracutaneous site. The tumorbearing mice were given regular food and water until the tumor diameter was at approximately $10 \mathrm{~mm}$.

\section{RESULTS AND DISCUSSION}

Design Strategy of Probe. As far as we know, until now, only our group has reported two fluorescent probes for the synchronous detection of $\mathrm{H}_{2} \mathrm{~S}_{n}$ and $\mathrm{O}_{2}{ }^{\bullet-}$ with high sensitivity and selectivity in living cells and in vivo. ${ }^{20,21}$ However, the 
previous works suffer from the interference from spectral overlap. To some extent, this will result in inaccurate detection during the testing process. To continue our research, we first strive to improve our probe's spectral properties. As shown in our previous examination, $\mathrm{H}_{2} \mathrm{~S}_{n}$ can more efficiently reduce the nitro group to an amino group than $\mathrm{H}_{2} \mathrm{~S}$ due to its stronger nucleophilic capability. We newly integrate an electronwithdrawing group 1-(3-nitrophenyl)ethanol into the mesoposition of a heptamethine cyanine dye as the $\mathrm{H}_{2} \mathrm{~S}_{n}$ receptor, which will quench the most of fluorescence of the cyanine fluorophore due to the photoinduced electron transfer (PET) process from the excited fluorophore to a strong electronwithdrawing group (donor-excited PET; d-PET), which is beneficial for the reduction of spectral overlap interference. Therefore, this nitrobenzene derivative plays multiroles, such as quenched unit, response unit, and leaving unit. The reducibility of the $\mathrm{N}^{+}$site of this cyanine platform is selected as the response site toward $\mathrm{O}_{2}{ }^{\bullet-20,21,49,50}$ Finally, we obtained a well-designed probe, $\mathrm{HCy}-\mathrm{ONO}$. The proposed reaction mechanism is illustrated in Scheme 1.

We hypothesized that the probe $\mathrm{HCy}-\mathrm{ONO}$ would first react with $\mathrm{O}_{2}{ }^{--}$through a hydrogen abstraction reaction to form CyONO and release relative low fluorescence. Subsequently, the reaction of the probe $\mathrm{Cy}-\mathrm{ONO}$ with $\mathrm{H}_{2} \mathrm{~S}_{n}$ resulted in the reduction of the nitro moiety to an amino group, followed by the 1,6-rearrangement-elimination reaction and thereby releasing the cyanine fluorophore with a remarkably large Stokes shift. ${ }^{51-53}$ By such a tandem reaction, the HCy-ONO achieved the sequential detection of $\mathrm{O}_{2}{ }^{\bullet-}$ and $\mathrm{H}_{2} \mathrm{~S}_{n}$ in different fluorescence collection windows with an extremely low background signal interference, which was rather advantageous to affording high detection sensitivity for $\mathrm{O}_{2}{ }^{--}$and $\mathrm{H}_{2} \mathrm{~S}_{n}$ detection. It is worth mentioning that nitro-aromatic compounds have been employed to develop fluorescent probes for the detection of nitroreductase in solid tumors under hypoxic conditions. ${ }^{51,53,54}$ However, the probe Cy-ONO could not offer a straightforward fluorescence response toward nitroreductase in the presence of reduced nicotinamide adenine dinucleotide (NADH; Figure $\mathrm{S} 1$ ). We attributed the phenomenon to the steric hindrance of our probe. Moreover, the fluorescence emission of these entire latent fluorescent probes are located in the near-infrared (NIR) region. The NIR fluorescence allows deep penetration into tissues and efficaciously avoids the influence of bioautofluorescence. ${ }^{36,55}$

Spectroscopic Properties toward $\mathrm{O}_{2}^{\bullet-}$ and $\mathrm{H}_{2} \mathrm{~S}_{n}$. The spectroscopic properties of the probe were examined under simulated physiological conditions (10 mM HEPES, pH 7.4). In the absence of $\mathrm{O}_{2}{ }^{--}, \mathrm{HCy}-\mathrm{ONO}(10 \mu \mathrm{M})$ exhibited no absorption and emission due to the polymethine $\pi$-electron system being destroyed by the formation of hydrocyanine. While addition of $\mathrm{O}_{2}{ }^{--}$triggered an absorption band centered at $765 \mathrm{~nm}$, indicating the recovery of a polymethine $\pi$-electron system of HCy-ONO and the formation of the probe Cy-ONO (Figure S2). The increasing concentrations of $\mathrm{O}_{2}{ }^{--}$induced a gradual increase in fluorescence intensity with a center at 785 $\mathrm{nm}$, which is located in the NIR region (Figure $1 \mathrm{a}, \Phi_{\mathrm{Cy}-\mathrm{ONO}}=$ 0.009 ). In order to quantitatively and accurately analyze $\mathrm{O}_{2}{ }^{\bullet-}$, we obtained a standard curve between fluorescent intensities $\left(F_{785 \mathrm{~nm}}\right)$ and $\mathrm{O}_{2}{ }^{\bullet-}$ concentrations. As shown in Figure $1 \mathrm{~b}$, the fluorescent intensities at $785 \mathrm{~nm}$ were linearly related to $\mathrm{O}_{2}{ }^{\bullet-}$ concentrations. The regression equation was $F_{785 \mathrm{~nm}}=7.58 \times$ $10^{4}\left[\mathrm{O}_{2}{ }^{--}\right]-7.36 \times 10^{4}$, with $r=0.9917$. The limit of detection was determined to be $90 \mathrm{nM}(3 \sigma / \mathrm{k})$ under
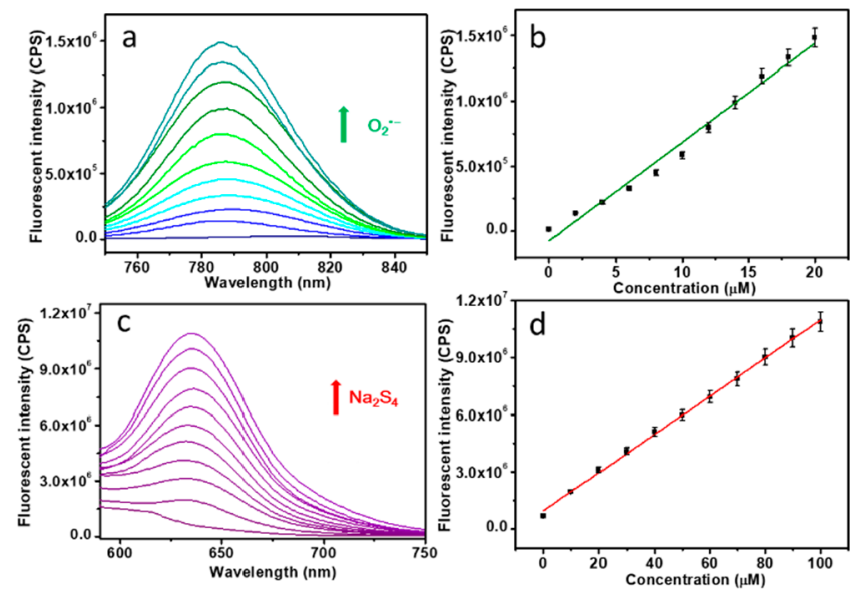

Figure 1. Properties of the $\mathrm{HCy}-\mathrm{ONO}$ and $\mathrm{Cy}$-ONO probes $(10 \mathrm{mM}$ HEPES, pH 7.4). (a) Fluorescence spectra of HCy-ONO $(10 \mu \mathrm{M})$ upon addition of $\mathrm{O}_{2}^{--}(0-20 \mu \mathrm{M})$. (b) The linear relationship between the fluorescent intensity and $\mathrm{O}_{2}{ }^{--}$concentrations. (c) Fluorescence spectra of $\mathrm{Cy}-\mathrm{ONO}$ upon addition of $\mathrm{Na}_{2} \mathrm{~S}_{4}(0-100$ $\mu \mathrm{M})$. The excess $\mathrm{O}_{2}{ }^{--}$was cleared by ascorbic acid. (d) The linear relationship between the fluorescent intensity and $\mathrm{H}_{2} \mathrm{~S}_{n}$ concentrations $(0-100 \mu \mathrm{M})$.

experimental conditions. These results demonstrated that the probe $\mathrm{HCy}-\mathrm{ONO}$ was capable of qualitatively and quantitatively detecting $\mathrm{O}_{2}{ }^{\bullet-}$ concentration under simulated physiological conditions. Next, we evaluated the fluorescent response of the probe $\mathrm{Cy}-\mathrm{ONO}$ for $\mathrm{H}_{2} \mathrm{~S}_{n}$ detection. The conjugate system was recovered via the oxidation of $\mathrm{O}_{2}{ }^{\bullet-}$, and then the excess $\mathrm{O}_{2}{ }^{\bullet-}$ was scavenged by ascorbic acid. After the addition of various concentrations of $\mathrm{H}_{2} \mathrm{~S}_{n}$, there appeared a strong fluorescent emission centered at $635 \mathrm{~nm}$ due to the removal of the d-PET process $\left(\Phi_{\text {Keto-Cy }}=0.365\right.$; Figure $\left.1 \mathrm{c}\right)$. Figure $1 \mathrm{~d}$ displayed a linear relationship between fluorescent intensities at $635 \mathrm{~nm}$ and $\mathrm{H}_{2} \mathrm{~S}_{n}$ concentrations. The regression equation was $F_{635 \mathrm{~nm}}=1.0 \times 10^{5}\left[\mathrm{H}_{2} \mathrm{~S}_{n}\right]+9.68 \times 10^{5}$, with $r=0.9991$. The experimental limit of detection was measured to be 100 nM. Therefore, the probe Cy-ONO could be used for the qualitative and quantitative detection of $\mathrm{H}_{2} \mathrm{~S}_{n}$ under simulated physiological conditions. In addition, $\mathrm{HCy}-\mathrm{ONO}$ and $\mathrm{Cy}$ ONO had a high selectivity for $\mathrm{O}_{2}{ }^{--}$and $\mathrm{H}_{2} \mathrm{~S}_{n}$ without any inferences (Figures S3 and S4). Moreover, the fluorescent intensity of our probes kept stable in HEPES buffer ranging from $\mathrm{pH} 3.0$ to $\mathrm{pH} 9.0$ (Figure S5).

Imaging of $\mathrm{O}_{2}{ }^{--}$and $\mathrm{H}_{2} \mathrm{~S}_{n}$ in Cells. We evaluated the utility of the probes for imaging of $\mathrm{O}_{2}{ }^{--}$and $\mathrm{H}_{2} \mathrm{~S}_{n}$ in living cells. Even at high concentrations, the probes $\mathrm{HCy}-\mathrm{ONO}$ and Cy-ONO exhibited low cytotoxicity (Figure S7). We then tested the utility of our probe to detect $\mathrm{O}_{2}^{\bullet-}$ and $\mathrm{H}_{2} \mathrm{~S}_{n}$ in the cellular environment (Figure S8). All the results of fluorescent response were further verified via flow cytometry assay (Figure S9). The dual-channel fluorescent images were obtained via fluorescence collection windows: from 750 to $850 \mathrm{~nm}$ (Channel I) and from 600 to $700 \mathrm{~nm}$ (Channel II). The cells in Figure S8a were incubated with $1 \mu \mathrm{M}$ HCy-ONO for $10 \mathrm{~min}$ as control. Prior to imaging, the cells were washed with PBS three times to remove the excess probe. Weak fluorescent signal was obtained in Figure S8a. After the same treatment as described in Figure S8a, the cells in Figure S8b were incubated with $10 \mu \mathrm{M} \mathrm{O}_{2}^{\bullet-}$ for $15 \mathrm{~min}$. As expected, the cells displayed an increase in fluorescence intensity. Subsequently, $50 \mu \mathrm{M}$ 

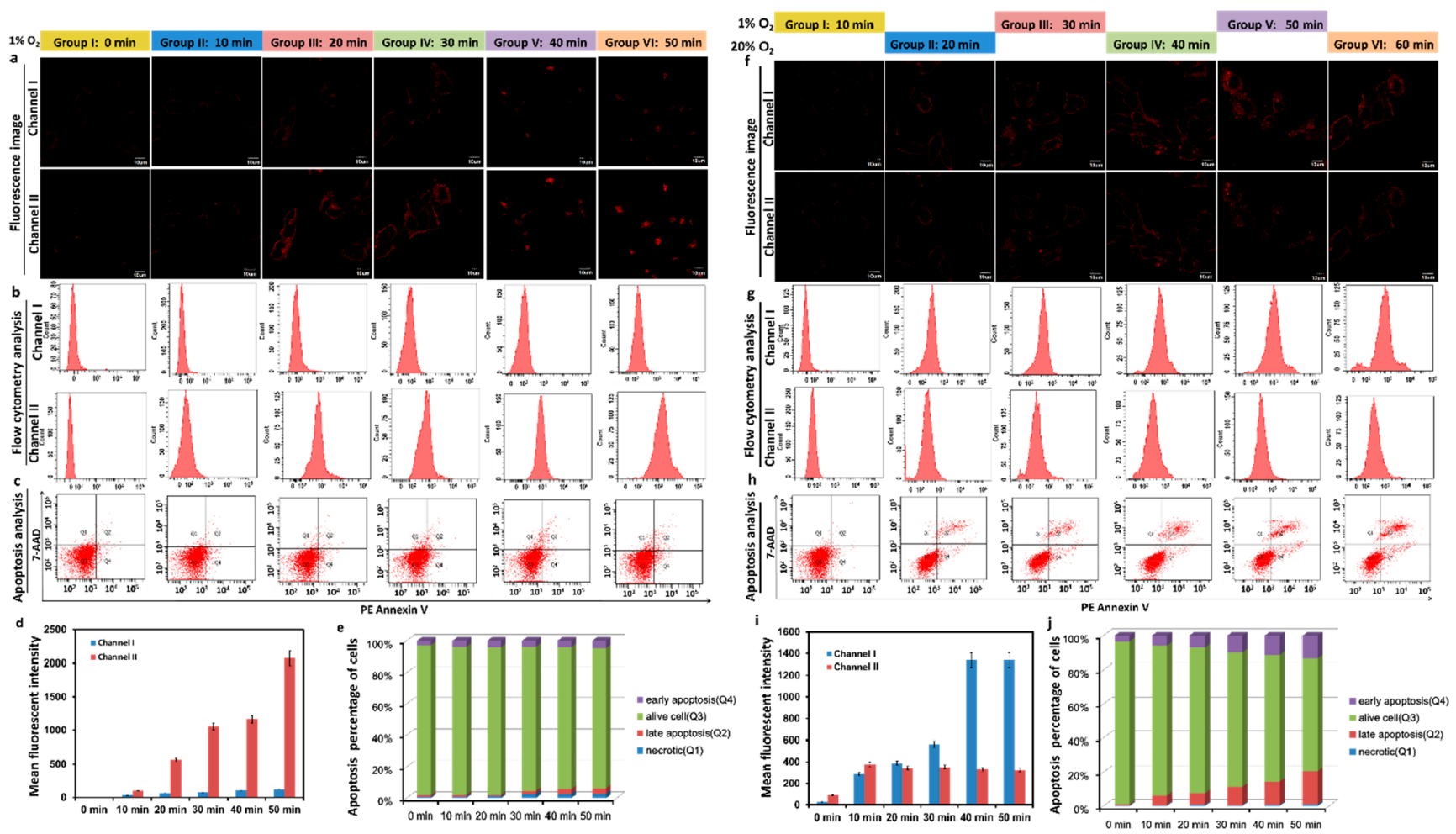

Figure 2. Fluorescent images (a), flow cytometry analysis (b), and apoptosis analysis (c) of SH-SY5Y during hypoxic condition ( $1 \% \mathrm{O}_{2}$ ) from 0 to $50 \mathrm{~min}$. The cells were placed in $1 \% \mathrm{O}_{2}$ condition for 0, 10, 20, 30, 40, and $50 \mathrm{~min}$. (d, e) Quantitation of the mean fluorescent intensity in (b) and apoptosis rate in (c) by flow cytometry assay. Fluorescent images (f), flow cytometry analysis (g), and apoptosis analysis (h) of SH-SY5Y during intermittent hypoxia. ( $\mathrm{i}, \mathrm{j}$ ) Quantitation of the mean fluorescent intensity in (g) and apoptosis rate in (h) by flow cytometry assay. Prior to imaging, all the cells were treated with $\mathrm{HCy}$-ONO $(1 \mu \mathrm{M})$ for $10 \mathrm{~min}$, and then washed with PBS for three times. Fluorescent signal collection windows were from 750 to $850 \mathrm{~nm}$ for channel I and from 600 to $700 \mathrm{~nm}$ for channel II. Apoptosis analysis: (Q1) necrotic, (Q2) late apoptosis, (Q3) alive cell, and (Q4) early apoptosis.

$\mathrm{Na}_{2} \mathrm{~S}_{4}$ was further added to the Petri dishes, there was an obvious fluorescent intensity increase (Figure S8c). Therefore, our probe was suitable for the detection of exogenous $\mathrm{O}_{2}{ }^{\bullet-}$ and $\mathrm{H}_{2} \mathrm{~S}_{n}$ in cells.

We next tried to detect the endogenous produced $\mathrm{O}_{2}{ }^{\bullet-}$ and $\mathrm{H}_{2} \mathrm{~S}_{n}$ using our probe. The burst of $\mathrm{O}_{2}{ }^{--}$was endogenously generated by stimulated cells with phorbol 12-myristate 13acetate (PMA). After pretreated with PMA for $30 \mathrm{~min}$, the cells in Figure S8d emitted an obviously fluorescent signal. To further confirm the selectivity of $\mathrm{HCy}-\mathrm{ONO}$ for intracellular $\mathrm{O}_{2}{ }^{\bullet-}$, we eliminated $\mathrm{O}_{2}{ }^{\bullet-}$ with a cell-permeable scavenger Tiron $(10 \mathrm{mM}){ }^{56}$ As expected, the fluorescent intensity decreased (Figure S8e). Accumulating studies showed that $\mathrm{H}_{2} \mathrm{~S}$ could be transformed into $\mathrm{H}_{2} \mathrm{~S}_{n}$ in the presence of ROS. After the same treatment with Figure S8d, the cells in Figure S8f were loaded with $\mathrm{H}_{2} \mathrm{~S}(50 \mu \mathrm{M})$ for $30 \mathrm{~min}$. As expected, a dramatic increase in fluorescent intensity was acquired, indicating the generation of $\mathrm{H}_{2} \mathrm{~S}_{n}$ (Figure S8f). It is worth noting that cystathionine $\gamma$-lyase (CSE) could promote the production of $\mathrm{H}_{2} \mathrm{~S}_{n}$. Lipopolysaccharide (LPS) could be used to enhance the CSE level and finally could increase the production of $\mathrm{H}_{2} \mathrm{~S}_{n}$. The cells were pretreated with LPS $(1 \mu \mathrm{g} /$ $\mathrm{mL}$ ) for $16 \mathrm{~h}$ before the same treatment in Figure S8d. Obviously, there was a dramatic fluorescence emission from cells in Figure S8g. As an additional experiment, the cells were incubated with a CSE inhibitor, DL-propargylglycine44 (PAG, $100 \mu \mathrm{M})$ for $10 \mathrm{~min}$ before the same treatment with Figure S8g. As expected, the fluorescent intensity was obviously attenuated, which indicated that CSE had a close relationship with $\mathrm{H}_{2} \mathrm{~S}_{n}$ generation (Figure S8h). These data demonstrated that our probe could be applied for the synchronous detection of $\mathrm{O}_{2}{ }^{\bullet-}$ and $\mathrm{H}_{2} \mathrm{~S}_{n}$ concentration changes.

Imaging of $\mathrm{O}_{2}{ }^{\bullet-}$ and $\mathrm{H}_{2} \mathrm{~S}_{n}$ under Hypoxic Condition. Hypoxia in cells induces redox imbalance, which further causes a series of physiological dysfunction. ${ }^{57,58}$ Therefore, the realtime trapping changes of redox state under hypoxic condition is convenient for investigation of a therapy method to effectively avoid cell damage. ${ }^{59}$ We next applied our probe $\mathrm{HCy}-\mathrm{ONO}$ to detect the real-time redox state between $\mathrm{O}_{2}{ }^{\bullet-}$ and $\mathrm{H}_{2} \mathrm{~S}_{n}$ under hypoxic condition at different time points (Figure 2a). Flow cytometry assay was conducted to further confirm these results (Figure 2b,d). Moreover, hypoxia induced apoptosis was evaluated by Annexin V-PE/7-AAD Apoptosis Detection Kit (Figure 2c). The cells in Figure 2a were incubated with $\mathrm{HCy}-\mathrm{ONO}$ and cultured under hypoxic condition $\left(1 \% \mathrm{O}_{2}\right)$. The cell culture medium was also deoxygenated with $1 \% \mathrm{O}_{2}$. As shown in Figure 2a, the fluorescent signals were collected from channel I (750-850 $\mathrm{nm}$ ) showed a slowly increase for $\mathrm{O}_{2}{ }^{--}$response during hypoxic time from 0 to $50 \mathrm{~min}$.

The fluorescent signals in channel II $(600-700 \mathrm{~nm})$ for $\mathrm{H}_{2} \mathrm{~S}_{n}$ detection also displayed increase during hypoxic period from 0 to $50 \mathrm{~min}$, which indicated the gradual increasing of $\mathrm{H}_{2} \mathrm{~S}_{n}$. It was easy to conclude that the cells suffered an imbalanced redox state under hypoxic conditions. We supposed that the increasing level of $\mathrm{H}_{2} \mathrm{~S}_{n}$ was consumed to eliminate the burst of $\mathrm{O}_{2}{ }^{\bullet-}$. However, the production of $\mathrm{H}_{2} \mathrm{~S}_{n}$ was limited. Finally, the level of $\mathrm{O}_{2}^{\bullet-}$ was uncontrollable. 

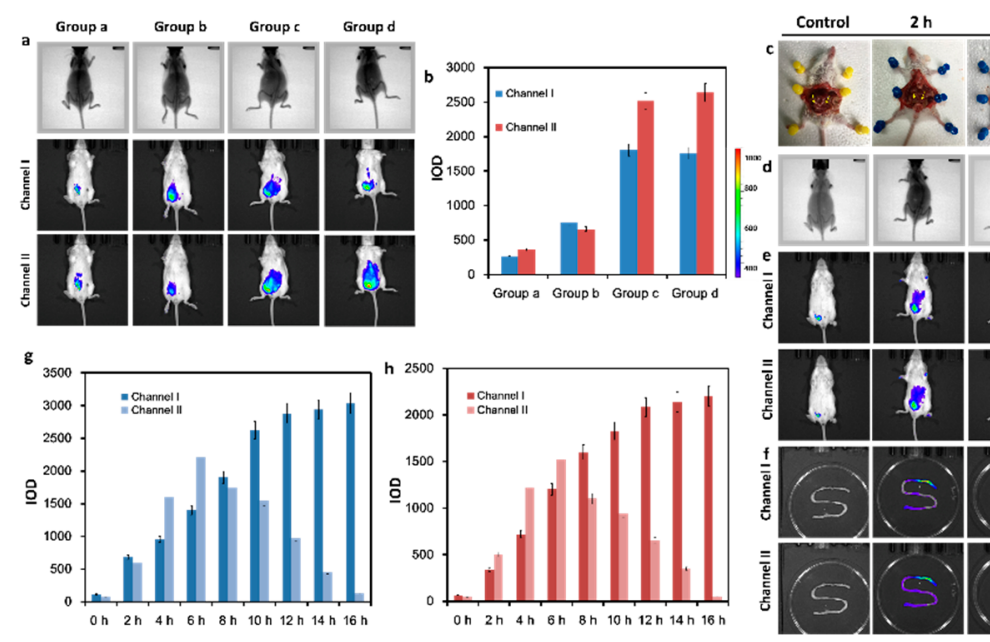

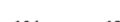

$14 \mathrm{~s}$ $16 \mathrm{~h}$
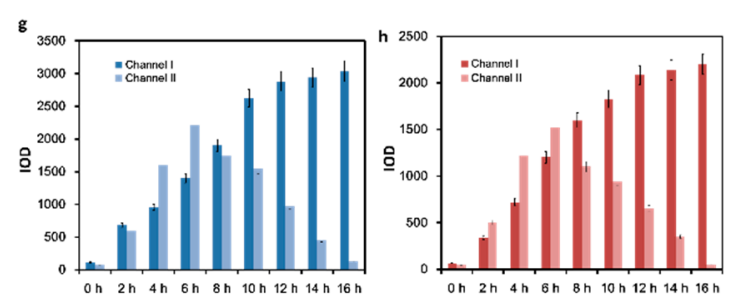

18

(8)
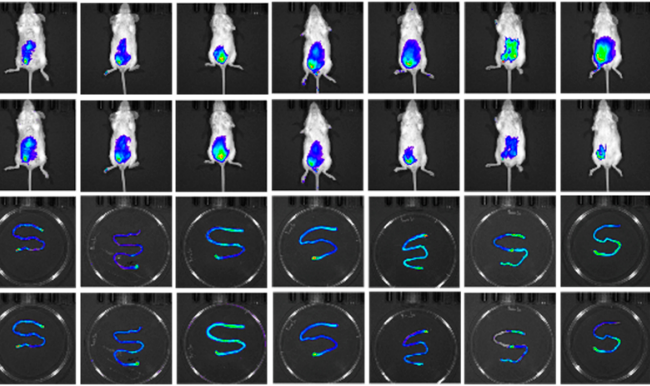

Figure 3. (a) Imaging of $\mathrm{O}_{2}{ }^{\bullet-}$ and $\mathrm{H}_{2} \mathrm{~S}_{n}$ in the peritoneal cavity of BALB/c mice. All experimental groups were given an intraperitoneal injection of HCy-ONO $(1 \mu \mathrm{M}, 100 \mu \mathrm{L}$ of $1: 99 \mathrm{DMSO} /$ saline $\mathrm{v} / \mathrm{v})$ for $30 \mathrm{~min}$ before in vivo imaging (Group a). The mice in Group b were injected intraperitoneal with PMA (100 nM, $100 \mathrm{~mL}$ in 1:9 acetonitrile/saline v/v) for $30 \mathrm{~min}$. The mice in Group c were given an intraperitoneal cavity injection with $\mathrm{Na}_{2} \mathrm{~S}_{4}(50 \mu \mathrm{M}, 100 \mu \mathrm{L}$ in saline) for $30 \mathrm{~min}$ after the same treatment with Group $\mathrm{b}$. The mice in Group $\mathrm{d}$ were performed as indicated in Group b, then injected with LPS $(10 \mathrm{mg} / \mathrm{mL}, 100 \mathrm{~mL}$ in $1: 9$ acetonitrile/saline v/v) for $12 \mathrm{~h}$. The fluorescent images constructed from emission intensities collected window, channel I: $750-850 \mathrm{~nm}, \lambda_{\mathrm{ex}}=730 \mathrm{~nm}$; channel II: $600-700 \mathrm{~nm}, \lambda_{\mathrm{ex}}=500 \mathrm{~nm}$. (b) Total photon flux from entire peritoneal cavity of the mice in Figure 3 a was quantified. Data are presented as mean \pm SD $(n=5)$. (c) The details of the acute peritonitis mouse models were obtained from the camera. (d) X-ray imaging in peritoneal cavity of the BALB/c mice. (e) Fluorescent intensity changes of $\mathrm{HCy}-\mathrm{ONO}$ in acute peritonitis mouse model. The mice were injection of $\mathrm{HCy}-\mathrm{ONO}(1 \mu \mathrm{M}, 100 \mu \mathrm{L}$ of 1:99 DMSO/saline v/v) for 30 min prior to in vivo imaging. (f) Fluorescent intensity changes of $\mathrm{HCy}-\mathrm{ONO}$ in small intestine of the acute peritonitis mouse model. (g, h) Total photon flux from entire peritoneal cavity of the mice in Figure $3 \mathrm{e}$ and small intestine in Figure $3 \mathrm{f}$ were quantified. Data are presented as mean \pm SD $(n=5)$.

During the cells were cultured under hypoxic condition for 50 $\mathrm{min}$, the rates of apoptosis were obtained as $4.7 \%, 5.9 \%, 6.2 \%$, $8.6 \%, 9.8 \%$, and $11.0 \%$, respectively (Figure $2 \mathrm{e}$ ). The increasing apoptosis rate revealed that hypoxia could induce cell apoptosis. These results showed that our probe could simultaneously detect $\mathrm{O}_{2}{ }^{--}$and $\mathrm{H}_{2} \mathrm{~S}_{n}$ level changes in living cells, which was of great importance to disclose the mutual relationship of $\mathrm{O}_{2}^{--}$and $\mathrm{H}_{2} \mathrm{~S}_{n}$ in living cells under hypoxic conditions.

To further test the feasibility of HCy-ONO for the sensitive detection of $\mathrm{O}_{2}{ }^{\bullet-}$ and $\mathrm{H}_{2} \mathrm{~S}_{n}$, we next attempted to change the culture condition of the cells by regulating the conditions of hypoxia. $^{46}$ As shown in Figure $2 \mathrm{f}$, the cells in the six independent groups (groups $\mathrm{I}-\mathrm{VI}$ ) were exposed in $1 \% \mathrm{O}_{2}$ for $10 \mathrm{~min}$, then treated in $20 \% \mathrm{O}_{2}$ for $10 \mathrm{~min}$, and the cycles were performed three times. The changes of intracellular $\mathrm{O}_{2}{ }^{\bullet-}$ and $\mathrm{H}_{2} \mathrm{~S}_{n}$ during this period were imaged by our probe. Compared with the cells cultured under continuous hypoxic conditions (Figure 2a), the cells with intermittent hypoxia displayed a fluorescent intensity increase (channel I), suggesting a burst of $\mathrm{O}_{2}{ }^{\bullet-}$ during the performance of intermittent hypoxia, while the fluorescence signals from channel II were almost unchanged and kept weak, indicating a low level of $\mathrm{H}_{2} \mathrm{~S}_{n}$ in these cells. The result implied that the high level of $\mathrm{O}_{2}{ }^{--}$during intermittent hypoxia would deplete a great amount of $\mathrm{H}_{2} \mathrm{~S}_{n}$. These results were consistent with flow cytometry assays (Figure 2g,i). The apoptosis rates of cells were further assessed by Annexin/7-77D Apoptosis Detection Kit. The apoptosis rates of cells were $4.5 \%, 12.2 \%, 14.6 \%$, $21.3 \%, 26 \%$, and $33.4 \%$, respectively (Figure $2 \mathrm{~g}, \mathrm{~h}$ ), which suggested that the apoptosis rates of cells under intermittent hypoxia were more severe than those under continuous hypoxic conditions (Figure 2c). Therefore, cellular hypoxia and reoxygenation were two key elements for ischemiareperfusion injury.
Discrimination of $\mathrm{O}_{2}^{\cdot-}$ and $\mathrm{H}_{2} \mathrm{~S}_{n}$ in an Acute Peritonitis Mouse Model. The NIR emission of our probe could achieve imaging of $\mathrm{O}_{2}^{\bullet-}$ and $\mathrm{H}_{2} \mathrm{~S}_{n}$ in vivo. BALB/c mice were selected to establish small animal models for our tests. The mice in Figure 3a were divided into four groups. All these groups were given an intraperitoneal (i.p.) injection of $\mathrm{HCy}$ ONO $(1 \mu \mathrm{M}, 100 \mu \mathrm{L}$ of 1:99 DMSO/saline $\mathrm{v} / \mathrm{v})$ for $30 \mathrm{~min}$ before in vivo imaging. The mice in Group a were set as control. The mice in Group b were given i.p. injection with phorbol myristate acetate (PMA, $100 \mathrm{nM}, 100 \mu \mathrm{L}$ in 1:99 $\mathrm{DMSO} /$ saline $\mathrm{v} / \mathrm{v}$ ) to promote $\mathrm{O}_{2}{ }^{\bullet-}$ production. The mice in Group c were given an i.p. injection of $\mathrm{Na}_{2} \mathrm{~S}_{4}(50 \mu \mathrm{M}, 100 \mu \mathrm{L}$ in saline) for $30 \mathrm{~min}$ after the same treatment as in Group b.

The mice in Group d were pretreated as described in Group $\mathrm{b}$ and then injected with LPS $(10 \mu \mathrm{g} / \mathrm{mL}, 100 \mathrm{~mL}$ in $1: 9$ acetonitrile/saline $\mathrm{v} / \mathrm{v}$ ) for $12 \mathrm{~h}$ to produce $\mathrm{H}_{2} \mathrm{~S}_{n}$. The fluorescent images were acquired using an in vivo imaging system. As shown in Figure 3a, weak fluorescent signals were obtained both in two channels of Group a. A strong fluorescence signal was found in channel I, while moderate fluorescent intensity was acquired in channel II of Group b. In contrast to Group a, Groups c and d exhibited strong fluorescence intensities both in channel I and in channel II. These results revealed that our probe could well penetrate to a deep depth and respond to $\mathrm{O}_{2}{ }^{\bullet-}$ and $\mathrm{H}_{2} \mathrm{~S}_{n}$ successfully.

Hypoxia exists in various diseases, especially in tumor and inflammation tissues. We next attempted to discriminate the inflamed tissue from normal tissue by imaging of the $\mathrm{O}_{2} \cdot-$ and $\mathrm{H}_{2} \mathrm{~S}_{n}$ levels in the mouse model. The acute peritonitis of the mouse model was established ${ }^{54}$ for investigating the level changes of $\mathrm{O}_{2}{ }^{--}$and $\mathrm{H}_{2} \mathrm{~S}_{n}$ in the inflamed tissue and normal tissue. As illustrated in Figure $3 c$, the acute peritonitis mice exhibited more serious edema, adhesion, and congestion in the enterocoelia than the normal mice. All mice were injected with HCy-ONO $(1 \mu \mathrm{M}, 100 \mu \mathrm{L}$ of 1:99 DMSO/saline $\mathrm{v} / \mathrm{v})$ for 30 
min prior to the in vivo fluorescence imaging analysis. Compared to the control group (Figure 3a), a significant increase in fluorescence intensity was obtained in the acute peritonitis mouse model (Figure 3e). The fluorescence images displayed a time-dependent increase in from 0 to $16 \mathrm{~h}$ in channel I (Figure 3g). However, the fluorescence images provided the fluorescence intensities as a hump profile in channel II. The strongest fluorescence intensity was obtained at $8 \mathrm{~h}$. To better comprehend the location of the fluorescence, the above described mouse model was dissected. We found that the main organ that emitted fluorescence was the small intestine, and the fluorescent intensities changed the same as those results in vivo (Figure $3 \mathrm{f}, \mathrm{h}$ ). Therefore, our probe $\mathrm{HCy}$ ONO could be used to discern inflamed tissue from normal tissue in vivo. The results demonstrated that there was a continuous formation of ROS in inflamed tissue. The burst of ROS would trigger the antioxidative supplement of $\mathrm{H}_{2} \mathrm{~S}_{n}$, but the rapidly rising levels of ROS would deplete too great an amount of $\mathrm{H}_{2} \mathrm{~S}_{n}$ to immediately produce.

Imaging of $\mathrm{O}_{2}{ }^{\circ-}$ and $\mathrm{H}_{2} \mathrm{~S}_{n}$ in Tumor-Bearing Mouse Model. Hypoxia is one of the typically observed milieus for malignant solid tumors in vivo. The hypoxic tumor holds a redox-imbalance status. The levels of ROS and $\mathrm{H}_{2} \mathrm{~S}_{n}$ in vivo have a close relationship with the tumor. Therefore, we struggled to trap the information between ROS $\left(\mathrm{O}_{2}{ }^{--}\right.$as a representative) and $\mathrm{H}_{2} \mathrm{~S}_{n}$ in the tumor, which would contribute to the development of an approach for cancer diagnosis and therapy. We utilized the probe HCy-ONO to the synchronous detection of $\mathrm{O}_{2}{ }^{--}$and $\mathrm{H}_{2} \mathrm{~S}_{n}$ in the SH-SY5Y tumor-bearing mouse model (Figure 4a). The probe $\mathrm{HCy}-\mathrm{ONO}(1 \mu \mathrm{M}, 50$

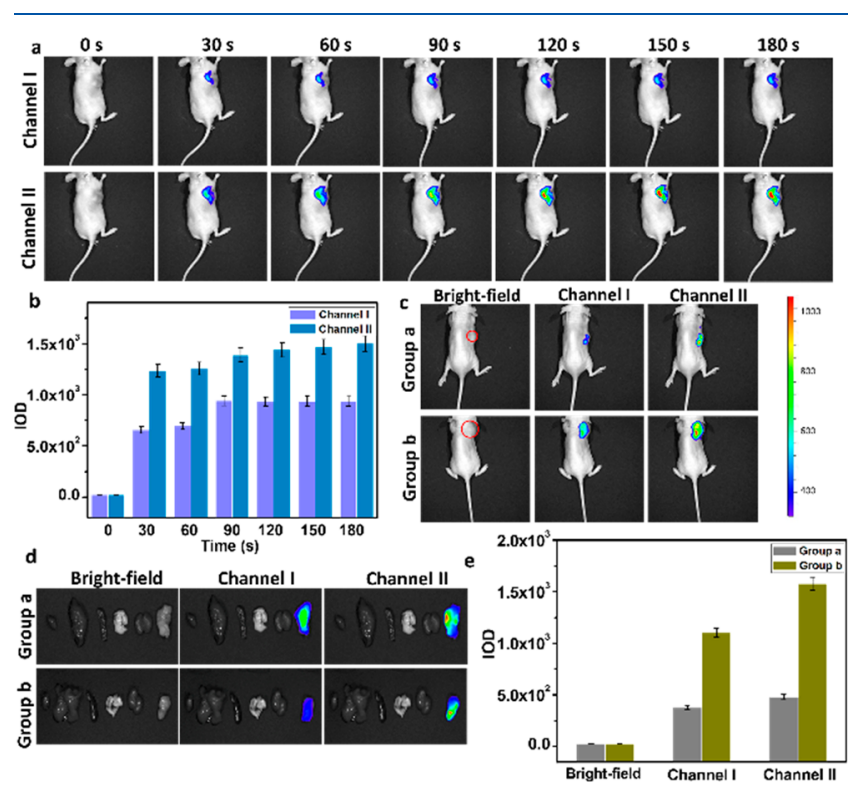

Figure 4. (a) Time-dependent fluorescent images in the SH-SY5Y tumor-bearing mouse model. The mouse was intratumoral injected with HCy-ONO $(1 \mu \mathrm{M}, 50 \mu \mathrm{L}$ in 1:99 DMSO/saline v/v). (b) Total number of photons from tumor region in Figure $4 \mathrm{a}$ was qualified. Data are presented as mean $\pm \mathrm{SD}(n=5)$. (c) In vivo imaging of different tumor sizes in the SH-SYSY tumor-bearing mouse model using HCy-ONO. (d) Fluorescence images of isolated organs. (e) Total number of photons from the tumor region in Figure $4 \mathrm{c}$ was qualified. Data are presented as mean $\pm \mathrm{SD}(n=5)$. The fluorescent images constructed from emission intensities collected window, channel I: $750-850 \mathrm{~nm}, \lambda_{\mathrm{ex}}=730 \mathrm{~nm}$; channel II: $600-700 \mathrm{~nm}$, $\lambda_{\mathrm{ex}}=500 \mathrm{~nm}$. Volume $=$ length $\times$ width $^{2} \times 0.5$. $\mu \mathrm{L}$ in 1:99 DMSO/saline $\mathrm{v} / \mathrm{v}$ ) was directly injected into the SH-SY5Y solid tumor with an intratumoral injection. The fluorescence emission collection windows were at $800 \pm 50$ $\mathrm{nm}$ (channel I) and $650 \pm 50 \mathrm{~nm}$ (channel II). After the intratumoral injection of $\mathrm{HCy}-\mathrm{ONO}$ into the mouse model, the fluorescent intensities in both of the channels gradually increased, and the highest fluorescent intensity occurred within 180 s. The fluorescence intensity at the injection site completely extended to the whole tumor over the injection time (Figure $4 \mathrm{~b}$ ). These results revealed that our probe could rapidly respond to $\mathrm{O}_{2}{ }^{\bullet-}$ and $\mathrm{H}_{2} \mathrm{~S}_{n}$ in the tumor region. We next wanted to track whether the fluorescence intensity was associated with the tumor size. Tumor volume was calculated according to the formula: volume $=$ length $\times$ width $^{2} \times 0.5$. HCy-ONO ( $1 \mu \mathrm{M}, 50 \mu \mathrm{L}$ in 1:99 DMSO/saline v/v) was intratumorally injected into different sized cancers (Group a, $v$ $=0.088 \mathrm{~cm}^{3}$; Group $\mathrm{b}, v=0.40 \mathrm{~cm}^{3}$ ) for the imaging of $\mathrm{O}_{2}{ }^{\bullet-}$ and $\mathrm{H}_{2} \mathrm{~S}_{n}$. As shown in Figure $4 \mathrm{c}$, tumor regions were selected as regions of interest. The large size tumor solid emitted stronger fluorescent intensity than that of the small size tumor solid. The fluorescent intensity of Group b was 3-fold that of Group a (Figure 4e). The fluorescence images of isolated organs further confirmed that our probe had almost no leakage to its adjacent organs (Figure $4 d$ ).

\section{CONCLUSIONS}

In summary, we have developed a nitrobenzene derivative functioned fluorescent probe $\mathrm{HCy}-\mathrm{ONO}$ for the sequential detection of $\mathrm{O}_{2}{ }^{\bullet-}$ and $\mathrm{H}_{2} \mathrm{~S}_{n}$ in cells and in mouse models under hypoxic stress. The detection principle used for probe design involves two chemical reactions: hydrogen abstraction reaction for the detection of $\mathrm{O}_{2}{ }^{\bullet-}$, and nitro reduction reaction followed by the 1,6-rearrangement-elimination to release cyanine fluorophore for the detection of $\mathrm{H}_{2} \mathrm{~S}_{n}$. The probe shows turn-on fluorescence response toward $\mathrm{H}_{2} \mathrm{~S}_{n}$ and $\mathrm{O}_{2}{ }^{\bullet-}$ in different fluorescence channels, which is allowing for imaging of intracellular $\mathrm{H}_{2} \mathrm{~S}_{n}$ and $\mathrm{O}_{2}{ }^{\circ-}$ with high sensitivity and selectivity. The probe $\mathrm{HCy}-\mathrm{ONO}$ can be used to synchronously capture the level changes of $\mathrm{O}_{2}{ }^{\bullet-}$ and $\mathrm{H}_{2} \mathrm{~S}_{n}$ in living cells under continuous hypoxic and intermittent hypoxic conditions. With the investigation of the relationship between $\mathrm{H}_{2} \mathrm{~S}_{n}$ and $\mathrm{O}_{2}{ }^{\bullet-}$ in the acute peritonitis mouse model, our probe can distinguish inflamed tissue from normal tissue. Finally, the probe is applied in the SH-SY5Y tumor-bearing mouse model for imaging of $\mathrm{O}_{2}{ }^{\bullet-}$ and $\mathrm{H}_{2} \mathrm{~S}_{n}$. These data demonstrated that different hypoxic status lead to different concentrations between $\mathrm{H}_{2} \mathrm{~S}_{n}$ and $\mathrm{O}_{2}{ }^{\bullet-}$. Our probe $\mathrm{HCy}-\mathrm{ONO}$ is of potential use for revealing the relationship between $\mathrm{O}_{2}{ }^{--}$and $\mathrm{H}_{2} \mathrm{~S}_{n}$ in different hypoxic conditions.

\section{ASSOCIATED CONTENT}

S Supporting Information

The Supporting Information is available free of charge on the ACS Publications website at DOI: 10.1021/acs.analchem.9b01189.

More experimental materials and details, synthesis steps, characterization of compounds $\left({ }^{1} \mathrm{H}\right.$ NMR, ${ }^{13} \mathrm{C}$ NMR, and MS), selectivity, and reaction kinetics (PDF)

\section{AUTHOR INFORMATION}

\section{Corresponding Authors}

*E-mail: fbyu@yic.ac.cn. 
*E-mail: dingcaifeng@qust.edu.cn.

*E-mail: 1xchen@yic.ac.cn.

\section{ORCID}

Fabiao Yu: 0000-0003-0073-6299

Lingxin Chen: 0000-0002-3764-3515

Notes

The authors declare no competing financial interest.

\section{ACKNOWLEDGMENTS}

We thank the National Nature Science Foundation of China (No. 21575159, No. 21775162, and No. 41776110), State Key Laboratory of Environmental Chemistry and Ecotoxicology, Research Center for Eco-Environmental Sciences, CAS (Grant KF2016-22), and the Key Laboratory of Sensor Analysis of Tumor Marker Ministry of Education, Qingdao University of Science and Technology (Grant SATM201705).

\section{REFERENCES}

(1) Kondoh, M.; Ohga, N.; Akiyama, K.; Hida, Y.; Maishi, N.; Towfik, A. M.; Inoue, N.; Shindoh, M.; Hida, K. PLoS One 2013, 8, No. e80349.

(2) Lluis, J. M.; Buricchi, F.; Chiarugi, P.; Morales, A.; FernandezCheca, J. C. Cancer Res. 2007, 67, 7368-7377.

(3) Rathore, R.; Zheng, Y. M.; Niu, C. F.; Liu, Q. H.; Korde, A.; Ho, Y. S.; Wang, Y. X. Free Radical Biol. Med. 2008, 45, 1223-1231.

(4) Yang, C.; Yang, Z.; Zhang, M.; Dong, Q.; Wang, X.; Lan, A.; Zeng, F.; Chen, P.; Wang, C.; Feng, J. PLoS One 2011, 6, No. e21971.

(5) Clanton, T. L. J. Appl. Physiol. 2007, 102, 2379-2388.

(6) Giles, G. I.; Tasker, K. M.; Jacob, C. Free Radical Biol. Med. 2001, 31, 1279-1283.

(7) Lin, V. S.; Chen, W.; Xian, M.; Chang, C. J. Chem. Soc. Rev. 2015, 44, 4596-4618.

(8) Gruhlke, M. C. H.; Slusarenko, A. Plant Physiol. Biochem. 2012, $59,98-107$.

(9) Kimura, H. Neurochem. Int. 2013, 63, 492-497.

(10) Ono, K.; Akaike, T.; Sawa, T.; Kumagai, Y.; Wink, D. A.; Tantillo, D. J.; Hobbs, A. J.; Nagy, P.; Xian, M.; Lin, J.; Fukuto, J. M. Free Radical Biol. Med. 2014, 77, 82-94.

(11) Park, C. M.; Weerasinghe, L.; Day, J. J.; Fukuto, J. M.; Xian, M. Mol. BioSyst. 2015, 11, 1775-1785.

(12) Takano, Y.; Echizen, H.; Hanaoka, K. Antioxid. Redox Signaling 2017, 27, 669-683.

(13) Nagy, P.; Winterbourn, C. C. Chem. Res. Toxicol. 2010, 23, $1541-1543$

(14) Predmore, B. L.; Lefer, D. J.; Gojon, G. Antioxid. Redox Signaling 2012, 17, 119-140.

(15) Chen, X.; Tian, X.; Shin, I.; Yoon, J. Chem. Soc. Rev. 2011, 40, $4783-4804$

(16) Nathan, C.; Cunningham-Bussel, A. Nat. Rev. Immunol. 2013, 13, 349-361.

(17) Gorrini, C.; Harris, I. S.; Mak, T. W. Nat. Rev. Drug Discovery 2013, 12, 931-947.

(18) Shibuya, N.; Tanaka, M.; Yoshida, M.; Ogasawara, Y.; Togawa, T.; Ishii, K.; Kimura, H. Antioxid. Redox Signaling 2009, 11, 703-714.

(19) Jackson, M. R.; Melideo, S. L.; Jorns, M. S. Biochemistry 2012, $51,6804-6815$.

(20) Huang, Y.; Yu, F.; Wang, J.; Chen, L. Anal. Chem. 2016, 88, $4122-4129$.

(21) Yu, F.; Gao, M.; Li, M.; Chen, L. Biomaterials 2015, 63, 93101.

(22) Yu, F.; Han, X.; Chen, L. Chem. Commun. 2014, 50, 1223412249.

(23) Chen, X.; Zhou, Y.; Peng, X.; Yoon, J. Chem. Soc. Rev. 2010, 39, $2120-2135$

(24) Yang, Y.; Zhao, Q.; Feng, W.; Li, F. Chem. Rev. 2013, 113, 192-270.
(25) Jung, H. S.; Chen, X.; Kim, J. S.; Yoon, J. Chem. Soc. Rev. 2013 42, 6019-6031.

(26) Yuan, L.; Lin, W.; Zheng, K.; He, L.; Huang, W. Chem. Soc. Rev. 2013, 42, 622-661.

(27) Gao, M.; Yu, F.; Chen, H.; Chen, L. Anal. Chem. 2015, 87, $3631-3638$

(28) Gao, M.; Wang, R.; Yu, F.; You, J.; Chen, L. Analyst 2015, 140, 3766-3772.

(29) Liu, C.; Chen, W.; Shi, W.; Peng, B.; Zhao, Y.; Ma, H.; Xian, M. J. Am. Chem. Soc. 2014, 136, 7257-7260.

(30) Chen, W.; Pacheco, A.; Takano, Y.; Day, J. J.; Hanaoka, K.; Xian, M. Angew. Chem., Int. Ed. 2016, 55, 9993-9996.

(31) Chen, W.; Rosser, E. W.; Zhang, D.; Shi, W.; Li, Y.; Dong, W. J.; Ma, H.; Hu, D.; Xian, M. Org. Lett. 2015, 17, 2776-2779.

(32) Zeng, L.; Chen, S.; Xia, T.; Hu, W.; Li, C.; Liu, Z. Anal. Chem. 2015, 87, 3004-3010.

(33) Shang, H.; Chen, H.; Tang, Y.; Guo, R.; Lin, W. Sens. Actuators, B 2016, 230, 773-778.

(34) Han, Q; Mou, Z.; Wang, H.; Tang, X.; Dong, Z.; Wang, L.; Dong, X.; Liu, W. Anal. Chem. 2016, 88, 7206-7212.

(35) Fang, Y.; Chen, W.; Shi, W.; Li, H.; Xian, M.; Ma, H. Chem. Commun. 2017, 53, 8759-8762.

(36) Ma, J.; Fan, J.; Li, H.; Yao, Q.; Xu, F.; Wang, J.; Peng, X. J. Mater. Chem. B 2017, 5, 2574-2579.

(37) Chen, W.; Rosser, E. W.; Matsunaga, T.; Pacheco, A.; Akaike, T.; Xian, M. Angew. Chem., Int. Ed. 2015, 54, 13961-13965.

(38) Guo, J.; Yang, S.; Guo, C.; Zeng, Q.; Qing, Z.; Cao, Z.; Li, J.; Yang, R. Anal. Chem. 2018, 90, 881-887.

(39) Yang, F.; Gao, H.; Li, S. S.; An, R. B.; Sun, X. Y.; Kang, B.; Xu, J. J.; Chen, H. Y. Chem. Sci. 2018, 9, 5556-5563.

(40) Zhang, Q.; Zhu, Z.; Zheng, Y.; Cheng, J.; Zhang, N.; Long, Y. T.; Zheng, J.; Qian, X.; Yang, Y. J. Am. Chem. Soc. 2012, 134, 1847918482 .

(41) Li, Y.; Wang, H.; Li, J.; Zheng, J.; Xu, X.; Yang, R. Anal. Chem. 2011, 83, 1268-1274.

(42) Yu, L.; Wang, S. L.; Huang, K. Z.; Liu, Z. G.; Gao, F.; Zeng, W. B. Tetrahedron 2015, 71, 4679-4706.

(43) Romieu, A. Org. Biomol. Chem. 2015, 13, 1294-1306.

(44) Kolanowski, J. L.; Liu, F.; New, E. J. Chem. Soc. Rev. 2018, 47, 195-208.

(45) Yu, F.; Li, P.; Wang, B.; Han, K. J. Am. Chem. Soc. 2013, 135, $7674-7680$

(46) Takahashi, S.; Piao, W.; Matsumura, Y.; Komatsu, T.; Ueno, T.; Terai, T.; Kamachi, T.; Kohno, M.; Nagano, T.; Hanaoka, K. J. Am. Chem. Soc. 2012, 134, 19588-19591.

(47) Liu, J.; Sun, Y. Q.; Huo, Y.; Zhang, H.; Wang, L.; Zhang, P.; Song, D.; Shi, Y.; Guo, W. J. Am. Chem. Soc. 2014, 136, 574-577.

(48) Long, C.; Wang, Y.; Herrera, A. H.; Horiuchi, K.; Walcheck, B. J. Leukocyte Biol. 2010, 87, 1097-1101.

(49) Kundu, K.; Knight, S. F.; Willett, N.; Lee, S.; Taylor, W. R.; Murthy, N. Angew. Chem., Int. Ed. 2009, 48, 299-303.

(50) Robinson, K. M.; Janes, M. S.; Pehar, M.; Monette, J. S.; Ross, M. F.; Hagen, T. M.; Murphy, M. P.; Beckman, J. S. Proc. Natl. Acad. Sci. U. S. A. 2006, 103, 15038-15043.

(51) Guo, T.; Cui, L.; Shen, J.; Zhu, W.; Xu, Y.; Qian, X. Chem. Commun. 2013, 49, 10820-10822.

(52) Shi, Y.; Zhang, S.; Zhang, X. Analyst 2013, 138, 1952-1955.

(53) Li, Z.; Li, X.; Gao, X.; Zhang, Y.; Shi, W.; Ma, H. Anal. Chem. 2013, 85, 3926-3932.

(54) Li, Y.; Sun, Y.; Li, J.; Su, Q.; Yuan, W.; Dai, Y.; Han, C.; Wang, Q.; Feng, W.; Li, F. J. Am. Chem. Soc. 2015, 137, 6407-6416.

(55) Gao, M.; Yu, F.; Lv, C.; Choo, J.; Chen, L. Chem. Soc. Rev. 2017, 46, 2237-2271.

(56) Yamada, J.; Yoshimura, S.; Yamakawa, H.; Sawada, M.; Nakagawa, M.; Hara, S.; Kaku, Y.; Iwama, T.; Naganawa, T.; Banno, Y.; Nakashima, S.; Sakai, N. Neurosci. Res. 2003, 45, 1-8.

(57) Piao, W.; Tsuda, S.; Tanaka, Y.; Maeda, S.; Liu, F.; Takahashi, S.; Kushida, Y.; Komatsu, T.; Ueno, T.; Terai, T.; Nakazawa, T.; 
Uchiyama, M.; Morokuma, K.; Nagano, T.; Hanaoka, K. Angew.

Chem., Int. Ed. 2013, 52, 13028-13032.

(58) Semenza, G. L. N. Engl. J. Med. 2011, 365, 537-547.

(59) Gao, M.; Wang, R.; Yu, F.; Chen, L. Biomaterials 2018, 160, 114 